\title{
Research on the Legal Liability for Bankcard Deposit Loss
}

\author{
Haijing Yang \\ An instructor in law institute, Tianjin Polytechnic University, Tianjin, China \\ E-mail: lawyerhaijing@gmail.com
}

$\begin{array}{lcc}\text { Received: July 4, } 2011 & \text { Accepted: October 14, } 2011 & \text { Published: February 1, } 2012 \\ \text { doi:10.5539/ass.v8n2p276 } & \text { URL: http://dx.doi.org/10.5539/ass.v8n2p276 }\end{array}$

\begin{abstract}
In view of bankcard deposit losses recently reported in newspapers, we should reconsider the legal relationship between the bank and the depositor. The thesis defines the nature of deposit contracts, expounds the rights and obligations of each party, draws the conclusions that: i) deposit contracts are consumer loan contracts in nature; ii) the bank enjoys the ownership of the deposits and undertakes all risks, and analyzes the liabilities of each party for deposit loss under different circumstance.
\end{abstract}

Keywords: Bank card, Deposit contract, Automatic Teller Machine (ATM)

\section{The origin and root of the issue}

\subsection{The origin}

More than 2.7 billion bankcards had been issued in China by various financial institutions nationwide by the end of 2009. (Note 1) Bankcards and Union Pay are changing our mode of life. Meanwhile, crimes against bankcards have been increasing. Criminals intercept information and pins by fixing card reader and cameras to ATMs and steal money from bankcards. Undoubtedly they are committing crimes and should be punished. However, there are disputes between banks and cardholders on such issues as who is the victim, who is responsible for deposit safety, and who shall bear the economic loss before the criminal case is solved.

(1) The bank insists that the criminal intercepts the information and the pins from the cardholder and gives the instruction through the ATM. After the bank computer system examines and verifies the pins, the bank will pay. So the payment is correct and valid. Therefore, the bankcard deposit loss has nothing to do with the bank.

(2) The cardholder insists that the bank fails to fulfill the obligation to protect the bankcard deposit, which results in the theft of information and pins. Therefore, the payment to the wrong man is invalid and the bank should bear the loss.

Bankcard deposit loss means the money is withdrawn by someone who is neither the cardholder nor an authorized agent. There are three major forms: by real bankcards, by duplicated bankcards, and by invading the bank computer system. Courts make different judgments on such cardholder vs. bank cases. The judge may

That the deposit in the bank card is stolen means the fund is expropriated by the man who is not the true depositor nor authorized by whom. There are three kinds of means, such as theft by the real bank card, by the copy card and penetration to the bank computer system. When the user files a lawsuit against the bank, the courts make the different decisions. The judge may

(1) decide for the plaintiff and the damages compensated. (Note 2)

(2) decide against the plaintiff and the damages not compensated. (Zhang Yuhui, 2006)

(3) decide that the two parties should share the loss according to the proportion of their faults. (Wei Shaoyong, 2009)

(4) decide to suspend the trial because the civil trial should be suspended before the criminal case is resolved. (Liu Bei, 2009)

\subsection{The root}

Probing into the different viewpoints and judgments above, we can find that the root lies in the misunderstanding of the nature of the savings contract and the deposit. The state protects by law the right of citizens to own legal income, deposit, real-estate and other means of subsistence, which was stipulated in the 1954 Constitution. Both 
the General Civil Law (1987) and Regulations on the Administration of Savings (RAOS, adopted at the 97th executive meeting of the State Council, promulgated by Decree No. 107 of the State Council of the People's Republic of China on December 11, 1992, and effective as of March 1,1993) stipulate that the depositor enjoys the ownership of the bank account funds thereafter. When the funds are gone, because of the long-standing cognition, the bank evades the responsibility and insists that the bank has nothing to do with it. It is not sure whether the criminal cases will be investigated and solved. Even the case was solved, the funds would have been dissipated and hard to recover and the depositor has to suffer great losses.

\section{The legal nature of the savings contract}

\subsection{The savings contract is a kind of deposit contract}

The word "deposit" as a noun refers to the money deposited in the bank. It can refer to a bank business that the bank and other qualified non-bank financial institutions (hereinafter referred to as "bank") accept the deposit money and repay the capital with interests upon the depositor's request. Based on depositors, the deposit can be classified into the corporate and the individual.

The former is compulsory and its customers are organizations, communities, schools, enterprises and institutions. It is regulated by laws such as The Law of Commercial Banks of the People's Republic of China(LCB) put into force on July 1st 1995 and amended in 2003, The Interim Regulation on Cash Management (IRCM), decree No.12 of the State Department, effective as of 1988, The Notice on Printing and Distributing Measures for the Administration of Renminbi Corporate Deposit, decree No.485, 1997 of the People's Bank of China, effective as of 1997, and The Regulation on Notice Deposit, decree No.3, 1999 of the People's Bank of China, effective as of 1999.

The latter is voluntary and its customers are urban and rural residents. It is regulated by laws such as Law on Commercial Banks (LCB), Regulations on the Administration of Savings (RAS), decree No.107, 1992 of the State Department, effective as of 1993, and Some Provisions on the Implementation of the Regulation on the Administration of Savings (SPIRAS), decree No.7, 1993 of the People's Bank of China, effective as of 1993.

Besides the customers, their objects, basic principles and concrete systems are also different. This thesis focuses on the latter.

\subsection{The savings contract is a kind of contract of consumer credit and the bank enjoys the ownerships of the deposit}

On the legal relationship between the bank and the customers, there are two debatable standpoints. One is a contract of consumer safekeeping, i.e., the safekeeping contract, and the other is a contract of consumer credit, i.e., the loan contract. The different viewpoints in the nature of the legal relationship mean a great deal to the ownership of the money in the bankcard.

The savings contract is not stipulated in the Contract Law of the PRC, and is a nameless contract. According to article 3 of the RAS, the savings as used herein means a business that the individual deposits RMB and foreign currency into the bank, and in return the bank issues a bank passbook as a record. The customer can draw his deposit with interests by presenting the bankbook and the savings institution should pay at sight according to the law. Starting from this definition, the thesis will research on the nature of the savings contract and draw the conclusion that the savings contract is a contract of consumer credit.

\subsubsection{Probe the nature of the savings contract from each party's intentions}

The depositor deposits the money in the bank for two aims, one is for storage, and the other is for the interests. This is the root why people have different opinions about the nature of the savings contract. Absorbing money is the principal debt business of banks, as well as the basis of asset business and intermediary business. The big interest rates margin between traditional deposit and loan business has been the source of bank profits. Deposit bearing interests is a fundamental principle in the deposit business. All central banks take interest rates as a tool to moderate deposit. The depositor lends the money to the bank to transfer the use of the money in exchange for interests. Therefore, when we probe the nature of the savings contract from the intentions, we come to the conclusion that the expectation on interests is greater than that on storage.

\subsubsection{Probe the nature of the savings contract from the subject matter of the contract}

Cash belongs to the "res" in the civil law system. As a chattel, cash has its special properties and functions different from common things. Firstly, cash is an indefinite thing and is highly substitutable. Neither the owner of the cash nor the creditor accepting the cash cares about its characteristics. Secondly, cash is a consumable thing. Once transferred, cash cannot be used by the former owner. From the saying "Cash belongs to the holder," 
we can conclude that the cash owner must be the holder. Acquiring the possession means acquiring the ownership. Losing the possession, and the ownership would be terminated. So when the depositor deposits cash to the bank and transfers the possession of the cash, he loses the ownership. (Zhang Qinglin, 2004)

\subsubsection{Probe the nature of the savings contract from the content of the deposit contract}

Firstly, pay the interests and keep confidential the privacy of depositors are the basic principles when a bank takes deposit. It is the bank, not the depositor, that pays the consideration all the times. Secondly, the bank does not have the obligation to keep the cash individually in different accounts. Thirdly, the bank can use the deposit. Capital financing is the basic and principal function of the bank. The bank can make use the deposit, engaging in issuing loans or other invested business. Lastly, the bank pays the deposit at sight of the bank passbook.

2.2.4 Probe the nature of the savings contract from the liquidation in the bankruptcy of the bank

According to article 71 of the LCB, while the bankrupt commercial bank is undergoing the process of account settlement, it should first pay the principal and interests of individual depositors after paying the fees for account settling, employees' wages and labor insurance which are in arrears. According to afore mentioned provisions, we can see that the relationship between the bank and the depositor is a credit and the depositor enjoys priority in compensation. And because of the special nature of cash, the depositor cannot exert the recall rights in fact.

\subsubsection{Probe the nature of the savings contract from the security system of the bank (Li Jiannan, 2007)}

At present bank communication networks are constructed by two ways, renting the digital data net (DDN) or accessing the DDN by the E1-based optical fiber, either of which is safe enough. As one kind of computer digital encryption, the bank terminal encryption is rather simple. In transit the bank communication net signal may be intercepted. And the stolen signal would be broken down and the deposit might be stolen. The bank has to face the fact. (Note 3) The economic-man theory of western classical economics tells us that a rational man will make his best to maximize his venture. If the bank owns the deposit, the bank will not ignore the case any longer. It has to adopt multiple protection technologies, upgrade the security system and strengthen the protection to remove the hidden danger.

To sum up, the savings contract is a kind of contract of consumer credit and the bank enjoys the ownership of the deposit. The depositor has the right to claim the deposit and its interests. And the bank has the obligation to pay the deposit and its interests on demand. The bank should bear the risks of the deposit, according to either the theory that the owner bears the risks or the theory that the optimal risk controller bears the risks.

\subsection{The nature of bankcards}

According to article 3 of RAOS, "savings" refers to those activities in which an individual deposits RMB or foreign currency in a bank while the bank issues a bankbook or deposit certificate in return; when the individual withdraws the principal and interests on his deposits against his bankbook or deposit certificate, the savings institution will pay him the principal and interests according to provisions.

According to article 2 of Measures for the Administration of bank card Business (MABCB, order of People's Bank of China, January 27th, 1999), the term "bank card" as mentioned in the Measures refers to the credit payment instruments issued by commercial banks (including postal financial institutions, the same below) to depositors, which have some of or all such functions as consumption credit, transfer and settlement, and depositing and withdrawing cash, etc; according to article 5, bankcards include debit cards and credit cards. The difference between the two cards is that the debit card, i.e. the savings card, cannot be overdrawn.

According to article 2 of Measures for the Administration of the Savings Card Business of China Construction Bank Limited (CCB), the term "savings card" refers to a multi-functional current deposit certificate in card issued by CCB to its depositor.

It is thus clear that the savings card is i) a savings certificate like a paper-bankbook issued by the bank, which plays the same role as a borrowing note used in private loaning, and at the sight of which the savings institution will pay the depositor the principal and interests on demand; ii) a financial instrument, with which you can consume, transfer and settle, deposit and withdraw cash. Thanks to the efficiency and convenience ATMs and Union Pay provide, bankcards have replaced the bankbook in a great degree.

\section{The obligations of each party under the savings contract}

\subsection{The obligation of the bank}

\subsubsection{The obligation to pay the principal and interests and provide other services}

According to article 29 of the LCB, commercial banks should follow the principles of voluntary deposit and free 
withdrawal, paying interests to depositors and keeping secret for depositors in handling individual deposits. Free withdrawal means the depositor has the right to decide when and how much to withdraw, and neither the bank nor other people can inquire or interfere, even if withdrawing his undue time deposits. The other services here include consumption credit, transfer and settlement. According to article 13 of SPIRAS, each savings bank shall guarantee the withdrawal of savings deposit, and shall not refuse it in any pretext.

3.1.2 The obligation to examine and verify

(1) The authenticity of the bankcard and the validity of the pins

According to article 3 of the Constitution of Peony Card of Industrial and Commercial Bank of China Limited (ICBC), and article 6 of the Constitution of Kins Card of the Agriculture Bank of China Limited (ABC), the cardholder can withdraw cash by using the debit card and the pins through ATMs of the bank in the whole country. The savings institution should verify that the card is real, not forged or falsified, i.e., the savings certificate is real, and that the pins are correct, i.e., the password is right.

(2) The identity of the drawee with large value business

According to the Notice of Administration on Paying Large Amount Cash, decree No.339, 1997 of PBC, and article 6 of the Notice of Strengthening the Administration of Financial Institutions on the Business about Individual's Deposit and the Withdrawal (NSAFIDW), decree No.363, 1997 of PBC, when the depositor asks to withdraw more than RMB 50 thousand at a time, the clerk of the financial institution authorized to handle the business about individual's deposit and withdrawal should demand him to present his identity card and check it before paying.

(3) The identity when the individual withdraws undue time deposit

According to articles 34 and 35 of the SPIRAS, a depositor shall hold his certificate of deposit and his own identity certificate (identity card, permanent residence booklet or military card for a Chinese, and passport or residence permit for a foreign depositor, similarly hereinafter) for withdrawing undue time deposit. If one acts as an agent for withdrawing undue time deposit, he shall also show his own identity certificate. In cases the drawee fails to present any valid identify certificate, the issue shall be decided by the department in-charge of the savings institution. For request of any depositor to withdraw the undue time deposit, the savings institution can, when the conditions prescribed in Article 34 of these Provisions are met, pay the undue time deposit after verifying that the name of the person who opened the certificate of deposit is identical with that on the certificate.

Here, "examine" means only "to check," not "to distinguish." The institutions only check whether the ID card or other identifications accords with the ID management provisions and whether the name on the ID card or other identifications accords with the name on the bankbook.

\subsubsection{The obligation to keep secret}

"Keep secret for the depositor" means that savings institutions and their personnel should keep the personal information of the depositor a secret and cannot disclose it, such as the name, address, savings amount, savings kind, deposit and withdrawal time, and signature etc. It is a basic principle that savings institutions must obey when handling the individual's deposit and withdrawal, and the foremost requirement to protect the interests of the depositor.

According to Article 32 of the RAOS, savings institutions and their personnel shall have an obligation to keep secret the depositor's savings and relevant information. Savings institutions shall not inquire into, freeze or allocate savings deposits on behalf of any unit or individual, unless otherwise provided for by laws and administrative regulations of the State. According to article 10 of the NSAFIDW, the People's Bank of China (PBC) and all its branches, as well as all financial institutions on the business about individual's deposit and withdrawal should keep the deposit secret for the depositor registered.

\subsubsection{The obligation to protect the deposit}

Commercial banks should be equipped with safe and effective computer systems to protect bankcard information and pins, establish a quick digital transfer network to quickly freeze the deposit when the depositor reports loss of the card, and perform routine maintenance for ATMs and POSEs to ensure a safe operation environment and leave no chance to criminals. 


\subsection{The obligation of the cardholder}

\subsubsection{The obligation to keep the bankcard, passwords and ID certificates with due care}

According to article 4 of the constitution of Peony Card of ICBC, the cardholder must set a password when applying for a peony card and all transactions using the password will be deemed to be operated by the cardholder himself. The password is an important means to verify the identity and trade content. The password is set and held by the depositor himself and accessed directly to the bank computer system. So the clerk knows only whether the password input is correct or not, but has not any idea what the password is. The cardholder will be held responsible for all transactions using the password, unless disclaimed responsibility by law.

\subsubsection{The obligation to notify the bank in time}

According to Article 37 of the RAOS, if the certificate of deposit or the deposit bankbook of a depositor is lost, he shall, upon the strength of his identity certificate and relevant conditions on his name, time, type and amount of deposit, account number and address, etc., immediately report the loss for payment suspension in written form to the savings institution where he opened the account. The savings institution can, after confirming that the deposit has not been withdrawn yet, accept the loss report. The depositor shall, seven days after the loss is reported, stipulate time with the savings institution for making up a new certificate of deposit or deposit bankbook or withdrawing the deposit. In cases the depositor cannot go to the savings institution for handling such formalities by himself, he can entrust someone else to handle it. However, the trustee shall present his identity certificate. In case If the depositor cannot handle the formalities in written form, he shall report the loss by telephone, telegraph or letter, and shall make up the formalities for reporting the loss in written form within five days after the original loss report, otherwise, the original loss report will be invalidated. If the deposit has been withdrawn before the loss is reported or the loss report is invalidated, the savings outlet institution shall not assume any liability. Once finding abnormal record, the depositor should check his account in time and notify his bank as soon as possible to prevent future loss.

\section{The obligation when the bankcard cash is stolen}

Analysis of legal liability for bankcard deposit loss

\subsection{Theft by the real bankcard}

Under this circumstance, it is unfair to conclude without exception that the depositor is responsible and therefore eliminate the bank's duty to pay. We should make a concrete analysis of concrete conditions.

\subsubsection{Analysis of legal liability}

(1) The bank pays the deposit proper and then the debt terminates

According to paragraph 1, article 60 of the Contract Law of the PRC, "the parties shall fulfill their respective obligation as contracted." The article embodies the principle of proper fulfillment of the contract. It requires the proper man fulfill his obligation as contracted targeted matter, quality, quantity on the proper date, in the proper place and by the proper way. When paying the deposit, if the bank fulfills the obligation to exam the password and, under some special circumstances, identity, it is a valid performance. So the depositor himself has to bear the loss because the cardholder uses the real card, shows the correct identity certificate and enters the correct password, which shows that the cardholder is the credit possessor. We can say that he is the quasi-possessor of the credit, even though he is neither the depositor himself nor the authorized person. It is a proper performance for the bank to pay the deposit in goodwill and without fault.

According to article 17 of The Measures for Payment and Settlement, if a bank, having conducted examination in good will and in compliance with the legal provisions and normal operating procedures, and found no abnormality in the signature and/or seal on a forged or unlawfully altered negotiable instrument or settlement certificate and the valid personal identification certificate presented for verification as required, makes the payment, the bank shall be no longer liable for making authorized payment for the drawer or drawee, nor shall it be liable for making payment to the holder or payee.

(2) The bank pays the deposit improperly, and the debt does not terminate

If the bank doesn't pay the deposit on the contracted way, such as, the bank pays the deposit after the depositor reports the loss for payment suspension, the transaction system is not advanced enough to protect the pins, or the bank personnel fails to verify the identity. Under such circumstances, the payment isn't proper and therefore the bank should assume the loss. There is an argument that if the parties are all in fault, each party shall share the loss in proportion according to the extent of their faults. The viewpoint is against the depositor. To draw the money, the real bankcard, the correct pins and ID authentication under given conditions are indispensable. The 
cardholder has reason to believe that so long as his pin wasn't stolen, his depositor is safe even if he lost his card. So the bank should bare all the loss if it cannot fulfill its obligation as contracted.

\subsubsection{Criteria of liability and the allocation of burden of proof}

The Contract Law adopts strict liability for breach of contract. According to article 107 of the Contract Law, "either party that fails to perform its obligations under the contract or fails to perform them as contracted shall bear the liability for breach of contract by continuing to perform the obligations, taking remedial measures, or compensating for losses." So long as one party breaches the contract, erring or not, he would bear the damages, unless the breaching party has the exoneration."

When it comes to the allocation of burden of proof, according to article 5 of Some Provisions of the Supreme People's Court on Evidence in Civil Procedures, "the bank should prove that it has perform its obligations as contracted, including that the transaction card is the real card, the payment procedure is proper, and the information is safe enough. The bank should keep the transfer and deposit records and the security tape."

\subsection{Theft by the copy card}

\subsubsection{Analysis of legal liability}

The bank has the obligation to pay the deposit at sight of the real deposit certificate. There is a basic premise to the principle of "the transaction regarded as operated by the cardholder himself" stipulated by article 4 of the Constitution of Peony Card of ICBC, i.e., the bankcard is real. If the card is a copy, even if the pins are correct, it would not be a valid payment (the payment would be invalid). If the bank couldn't discriminate whether the card is real or not and pays the deposit on the forged, falsified or copy card, it is an improper performance. According to article 69 of Some Provisions of the Supreme People's Court on Bill Disputes, "the drawee or his agent who makes payment out of ill intention or with gross negligence, for example, he could not identify the forged or falsified card or ID certificate, shall bear liability on his own. The drawee or his agent, after his assumption of the liability, shall be entitled to recourse against the forger or falsifier."

But it is unfair to conclude that the bank bears the loss totally in cases with copy cards, and it may induce moral hazard. For example, the depositor may, on his own initiative, tell the pins to others, who then withdraw the money with a copy card. So it will be more rational to conclude that the bank could take evidences of exemption that the cardholder is intentional about the loss as the defenses to reduce or waive its liability.

The bank should improve the anti-counterfeit technology and capacity to identify so as to prevent false transaction as possible as the technology circumstances will permit.

\subsubsection{Criteria of liability and the allocation of burden of proof}

This kind of cases shares the same criteria of liability with those mentioned in section 4.1.2, i.e., the strict liability. As of the allocation of burden of proof, the bank should present the evidences to prove that it has fulfilled his obligation properly. And the cardholder has only to provide the evidences that he held the real card, i.e., he has kept the card properly.

\subsection{The criminal hacks into the bank system and steals the money}

Under this circumstance, if the bank system itself has security holes, the bank should bare the loss. The question is, if the bank system is safe enough, whether the bank can avail itself of the defenses, such as Force Majeure or inevitable accidents, to exempt from its liability or mitigate its liability. Some scholars argue that if the two parties have no fault, they should share the loss according to the principle of justice provided by the General Civil Law. Actually that was not the case. As stated above in section 2.2, the bank enjoys the ownership of the deposit and takes risks accordingly, so the bank itself should bare the loss if the loss is resulted from Force Majeure or inevitable accidents. Moreover, it is impractical to demand the depositor to prove whether the bank system meets the safety requirements. Therefore, the bank has to bare the loss totally.

In short, with more and more disputes involving bankcards, it is a premise to solve these cases that we specify the legal nature of the savings contract, make sure the ownership of the deposit and define the rights and duties of each party. The bank enjoys the ownership of the deposit and takes risks accordingly. So long as the bank pays the deposit by the due process, the payment is a valid performance. Except that, the bank has to bare the loss unless the depositor is intentional about the loss.

\section{References}

Li, Jiannan. (2007). how to realize the deposit? (New thoughts on the legal nature of deposit behavior) National People's Congress. copy data. Civil and Commercial Law, (5)62. (in Chinese) 
Liu, Bei. (2009). The deposit stolen, the case accepted. Chutian Golden Newspaper, June 25. (in Chinese)

Wei, Shaoyong. (2009). How to share the liability of deposit loss caused by misbelieving information posted on ATMs. The People's Judicature, (4):64. (in Chinese)

Zhang, Qinglin. (2004). Cash's property (Property of Currency). Law Review, (5)52. (in Chinese)

Zhang, Yuhui. (2006). The classification and the liability of savings contract disputes. Economics and Law, (4):189. (in Chinese)

Zhu, Daqi. (2007). Financial Law. Beijing: China Renmin University Press.

Notes

Note 1. More than 2 billion bankcards issued. http://news.zman.cn/caijingyaowen/wgyhkfkc_cijghh.htm,2010.3 (in Chinese)

Note 2. The depositor wins the bank indemnity. http://www.tj.xinhuanet.com/news/2010-04/09/content_19475331.htm (in Chinese)

Note 3. Seminar on disputes involving bankcards (in Chinese), http://www.civillaw.com.cn/article/default.asp?id=45825, 2010.2 (in Chinese) 